\title{
Effects of Conflicts over Common Pool Resources on Gender among the Residents of Lower River Nyando Floodplains, Kisumu County, Kenya
}

\author{
Paul Okello Atieno ${ }^{1}$ \\ Samson Wokabi Mwangi ${ }^{2}$ \\ Kibet Ngetich ${ }^{3}$
}

\author{
$\mid \begin{aligned} & \text { 1,2,3 Egerton University, Egerton, Kenya } \\ & \text { ( Corresponding Author) }\end{aligned}$
}

\begin{abstract}
Common pool resource conflicts affecting communities' livelihoods are becoming very relevant in natural resource research as it is now accepted as one of the key factors leading to poverty and loss of livelihood, although specific effect on gender is lacking. This study examined the effect of conflict over common pool resources upon gender, of varying age groups, among the residents of lower river Nyando flood plains in Kenya. The study locates use of common pool resources like water, fish, papyrus resources, and land as source of conflict among the residents of this area. The objectives were to identify the frequency of conflict, the results of conflict, and the effect of conflict over common resources on gender among the residents of Lower River Nyando flood plains. Descriptive research design was adopted for the study, and purposive and stratified sampling technique used to select 138 respondents, who were interviewed using interview schedules. Cronbach's Alpha was used to test instrument's reliability, and a coefficient of $76 \%$ was attained. Gender was categorized as women, men, elders, youth, and disabled, and amongst these, women were the most affected owing that most farming, papyrus harvesting, and dairy products benefit women most in households in this region. Similarly, displacement of men from grazing fields, farming, and use of water resulted into loss of income, dairy resources, and nutrition. Women, being reliant on exploitation of papyrus, lost income from this CPR conflict due to destruction of harvested papyrus and exclusion from the right to cultivate crops on disputed land. It was concluded that there is a significant relationship between gender and resource exploitation, hence conflicts relating to CPRs have gender specific effects.
\end{abstract}

Keywords: Conflict, Effect of conflict, Lower, River Nyando floodplains, Gender, Common pool resources, Flood plains, Livelihood.

\section{Contents}

1. Introduction .

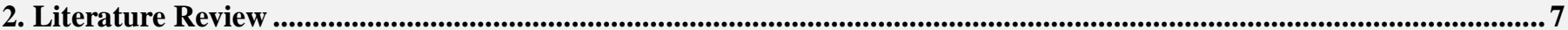

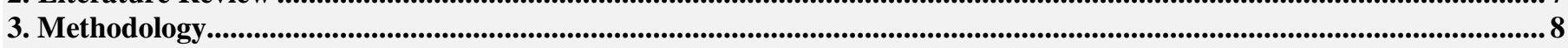

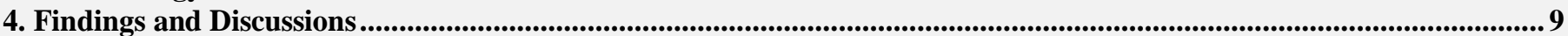

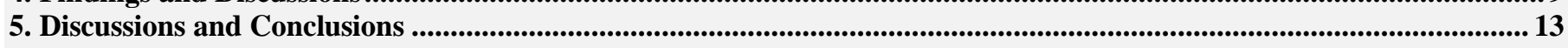

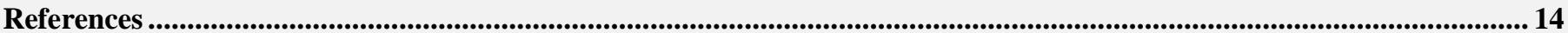

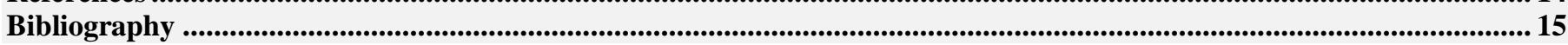

Citation | Paul Okello Atieno; Samson Wokabi Mwangi; Kibet Ngetich (2016). Effects of Conflicts over Common Pool Resources on Gender among the Residents of Lower River Nyando Floodplains, Kisumu County, Kenya. World Scientific Research, 3(1): 6-15.

DOI:

$\operatorname{ISSN}(\mathbf{E})$ :

$\operatorname{ISSN}(\mathbf{P})$ : 10.20448/journal.510/2016.3.1/510.1.6.15 Crossref

Licensed: $\quad$ This work is licensed under a Creative Commons Attribution 3.0 License $((c))$ EY

Contribution/Acknowledgement: All authors contributed to the conception and design of the study. The authors are most grateful to all the residents of lower River Nyando floodplains for their responses during data collection process. We are equally indebted to the provincial administration, Sub County Education Officers and elders of both Nyakach and Nyando Sub-Counties whose contributions were very invaluable to the study.

Funding: This study received no specific financial support.

Competing Interests: $\quad$ The authors declare that they have no conflict of interests.

$\begin{array}{ll}\text { Competing Interests: } & \text { The authors confirm that the manuscript is an honest, accurate, and transparent account of the study was reported; that no } \\ \text { Transparency: } & \text { The }\end{array}$

Ethical:

History: vital features of the study have been omitted; and that any discrepancies from the study as planned have been explained. This study follows all ethical practices during writing.

Publisher: 


\section{Introduction}

Since natural resources are intrinsically linked with many aspects of the production systems, their use generates numerous conflicts across Africa. These range from competition over scarce resources, like grazing lands and water points, to disputes over land boundaries and ownership rights, to arguments over the access and use of common-pool resources such as forests [1].

Conflicts over common pool resources can be divided into several categories according to scale: conflict among members of the same community (community-level), between two communities (inter-community), or involving more than two communities (supra-community), as expressed by Sanginga, et al. [2] and Edossa, et al. [1]. There are also conflicts at the farm level that involve individual farmers or farmer(s) and a group of farmers [3]. These conflicts have been increasing with the population and land degradation, both of which lead to higher pressure on land. Even though the majority of the natural resource conflicts happen on the local level, most of these conflicts have effects that stretch beyond the local level to involve actors at other levels. Sanginga, et al. [2] aver that the intensity of such conflicts varies from local disputes to violent clashes between clans, communities, or local groups over common pool resource ownership rights and responsibilities.

Although the smaller localized disputes may be effectively resolved, even the petty conflicts related to natural resources can linger under the surface for generations to one day erupt into large-scale inter-ethnic violence [3].

Such conflicts often result into loss of life, waste of human capital, and depletion of resources which support individual as well as community livelihoods, thus jeopardizing the long- term co-existence of communities or groups etc. In more extreme cases, bloodshed and loss of life are possible outcome of these clashes [4]. For instance, the genocide in Rwanda in the 1990s was rooted in the conflicts over scarcity of arable land in the south of the country [5].

Any type of conflict negatively affects the livelihoods of the resource-dependent communities as well as society as a whole. Perhaps the most costly land conflict in Sub-Saharan Africa is the conflict around land in Zimbabwe, which has undoubtedly contributed to the decline in the economic growth in Zimbabwe that has since collapsed beyond recovery [6-8]. Deininger and Castagnini [3] examined the productivity impact of land conflicts in Uganda caused by unclear tenure rights, competition between traditional and modern rights systems, inheritance disputes, and weak institutional environment to support land reforms. They Deininger and Castagnini [3] concluded that conflicts lower land productivity by inflicting crop damage, including perennial crops, leaving land unused as a result of fear to cultivate, and undermining land markets.

Such outcomes lead to low productivity of land, further subjecting the less fortunate members of the community like widows to make little use of their land by depriving them of potential rental income and crop harvest, and causing an overall sub-optimal economic and social land use. Thus, economic loss is a common outcome of landrelated conflicts. A study by Thebaud and Batterbury [9] found that resources, such as water, can be in the center of a long-term violent conflict as in the example of the conflict over access to wells and boreholes between Fulani and Tubu tribes in eastern Niger.

This prolonged conflict between the two herder groups has had a serious impact on market activities and economic development of the region Nkonya and Markelova [10]. Conflicts over commons in Africa (and Kenya, for that matter) often involve two different communities (inter communal) or tribes (tribal conflicts), and common pool resource conflicts involving members of the same community has not been highlighted. Further, the effect of intracommunal conflicts on gender has received little attention compared to reactive steps that have been taken by the Government in controlling or managing such conflicts. This study was set to establish the effects of conflict over common pool resource on gender among residents of Lower River Nyando.

\section{Literature Review}

Coping and adaptive strategies of rural people and sustainable livelihoods provides a strong link for the focus on common pool resource use $[11,12]$. For many households in rural areas of Asia, Africa, and Latin America, access to common pool resources represents the chance for a growing income, a means to invest in children's education, and a route out of poverty $[13,14]$. Development scholars have documented a steady decline in the income of these families due to conflicts involving different communities either amongst themselves or between the (communities) and conservationists or large scale investors [15].

The undermining of poor people's access to common-pool resources through the transfer of resource use rights for large-scale commercial exploitation, through international or domestic private-sector investment [16] has driven the poor who relied on such resources to be dependent on informal wage engagement from the large scale commercial investors, further undermining livelihoods among the rural poor.

The rural populations which primarily depend on agriculture often suffer from prolonged poverty from the rapid pace of consolidation in landholding, the widespread nature of land conflicts, and the systemic failures to resolve these conflicts. Conflicts over access to agricultural land, as well as the common-pool resources of forests and fisheries, thus lead to broader social instability and further violence [17].

Conflict over grazing land in Uganda between Balalo and Basongora pastoralists left several herdsmen dead [18]. The two communities depend entirely on open grazing fields and conflict over such grazing land means exposure to biting poverty resulting from the loss of dairy and meat products given that there is lack of grazing fields, hence eliciting extreme violent reactions against such exclusion from this open access resource. In other extreme case, landed conflicts can result into a complete and hard-to-redeem decline in national economy, as witnessed in Zimbabwe [6-8]. 


\section{Methodology}

\subsection{Study Area}

Administratively, Lower River Nyando Flood Plains is found in Lower Nyakach and Nyando division [19]. The area is served by two rivers; Nyando and Awach, which during heavy rainy seasons cause floods in Lower Nyando Flood Plains. The residents from the two locations, however, often use water from the two rivers for rice cultivation by irrigation. The type of soil and climate in Nyando district, particularly in Muhoroni, Miwani, and parts of Nyando Division is suitable for sugar cane cultivation, and this (Sugar cane farming) forms the main cash crop in the entire district. Along Nyando and Awach rivers, there are swamps which residents from the two divisions use for rice growing. The greatest concern in the two divisions is low access to clean and safe water, and water born diseases are frequent among households in these two areas. The district is prone to flooding during the wet season thus resulting in contamination of water sources. Industrial discharges into the lake and vehicle washing along the shores have also contributed to contaminated water for the residents. The other extreme condition is drought, when people have to walk long distances in search of water or rely on unsuitable water from ponds which is shared with livestock. Although the district has potential for the development of the key sectors of the economy, the level of development is low due to failure in exploiting the full potential. The agriculture sector is not performing to the required level, resulting in low overall food production. The district has to rely on food imported from outside to supplement locally produced food. After the collapse of the cotton industry, cotton growing was abandoned by farmers thus worsening income levels. In terms of livestock, the district relies on traditional animals instead of improved ones that would be more economical to the district. Due to poor farming practices coupled with lack of concern for tree planting, the district is suffering from soil erosion and environmental degradation.

Similarly, fishing as a source of food and income has been seriously affected by the invasion of the water hyacinth on one hand, and poor fish price occasioned by the spread of fish farming propagated by various NGOs operating in the area. Two locations (Wawidhi and North Nyakach) provided data for the study, whereby Gem Nam and Gem Rae sub-locations were selected from North Nyakach, and Magina, Kakola, and Kochogo were selected from Wawidhi location. The map in Figure 3.1 illustrates the study area.

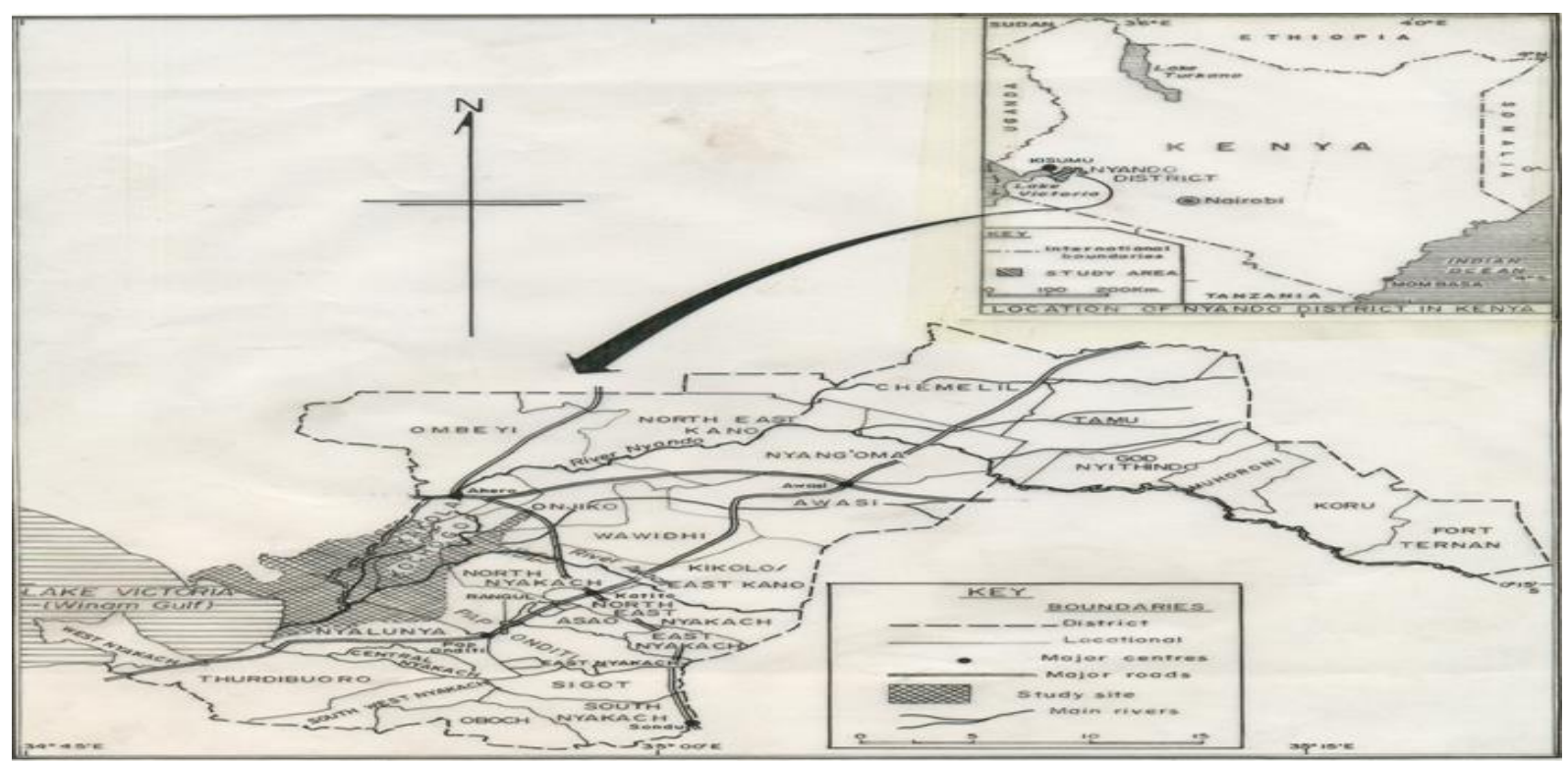

Figure-3.1. Map of Kenya, showing the study location

Source: Cartographer Egerton University (2014)

\subsection{Population, Sampling Procedure and Data Collection}

Stratified and purposive random sampling techniques were used to select 138 respondents from the 6370 households and a table of values was then used to obtain the required sample size.

This study used interview schedules and observation guides to gather the necessary data. Interview schedules were used to elicit data from the heads of households sampled from the families living within the study area. Administration of interview schedules allowed the researcher to make clarifications on questions not clearly understood by the respondents and to probe further so as to obtain precise information of the study phenomena.

Instruments used to collect the required data were pilot tested in Ombeyi sub-location, far away from the area under study, since it (Ombeyi sub-location) had similar characteristics. The instruments yielded Cronbach's reliability coefficient alpha value of $76 \%$. From the attached map, Ombeyi sub-location is far from the areas under study and this reduced the effect of contamination. For the purpose of ensuring reliability and validity of the instruments, the researcher checked for representativeness of data, bias due to observer bias or the influence of the researcher on the research situation, cross-check data with evidence from other independent sources, and comparing and contrasting the data during the stage of qualitative investigation on the conflicts. Through pilot testing, the instruments were reorganized and some parts deleted to enable the researcher to get a working instrument. The final instrument was therefore trusted to be capable of yielding consistent results

\subsection{Data Analysis and Presentation}

Based on the research instruments and data collected, data was organized, processed and analysed using descriptive statistics. In the field, the researcher ensured that questions were answered correctly to give accurate information. The researcher took keen interest to establish how the people of lower River Nyando floodplains 
responded to the questions asked in line with the objectives of the study. For the purposes of data entry, the researcher coded the data by assigning numerical values to the qualitative data, for analysis. This enabled the disassembling and reassembling of data: codes are often used to pull together and categorise a series of otherwise discrete events, statements and observations which they identify in the data.

Descriptive statistics was employed to organize and describe the sampled population. Data was processed on computer using Statistical Package for Social Sciences (SPSS). Tables and charts were used to present the analysed data.

\section{Findings and Discussions \\ 4.1. Findings}

In order for the researcher to establish the actual effect of conflict over common pool resources among the residents of Lower River Nyando flood plains, the frequency of conflict occurrence was analysed.

\subsubsection{Frequency of Conflict over Water}

It was imperative to assess the frequency of conflicts over water, as one of the resources in the flood plain so as to enable the researcher to establish the gross effect of such conflict on different gender groups. Water is an essential resource since its use affects various activities on a daily basis in the flood plain. The frequency of conflicts over water resources was categorized on a weekly, monthly and quarterly basis as shown in Table 1.

\begin{tabular}{l|l|l} 
Table-1. Frequency of conflicts over Water \\
\hline Frequency of Conflict & Frequency & Percent \\
\hline Weekly & 22 & 16 \\
\hline Quarterly & 47 & 34 \\
\hline Monthly & 69 & 50 \\
\hline Total & $\mathrm{N}=138$ & 100 \\
\hline Source: Researcher data 2014 &
\end{tabular}

Source: Researcher data 2014

Table 1 illustrates that majority $(50 \%)$ of the respondents indicated that conflicts over water occurred on a monthly basis while $34 \%$ reported a quarterly basis and finally $16 \%$ weekly. The monthly occurrence of conflict over water resources may imply that the feuding clans often regroup and plan attacks on their counterparts, probably in revenge to a previous similar attack.

\subsubsection{Frequency of Conflict over Papyrus and Related Resources}

Growing naturally in swampy places, papyrus is one of the resources which are exploited by the residents of the flood plain. Similarly, other reeds and grasses which grow in the flood plain, including the water hyacinth, are also exploited. Knowledge of the frequency of conflicts over these resources can help in proposing peace interventions in a timely manner. Table 2 illustrates the responses regarding the frequencies of conflicts over papyrus and related resources.

\begin{tabular}{l|l|l} 
Table-2. Frequency of Conflicts over Papyrus, reeds, and other grasses \\
\hline Frequency of Conflict & Frequency & Percent \\
\hline Weekly & 67 & 49 \\
\hline Monthly & 71 & 51 \\
\hline Total & $\mathrm{N}=138$ & 100 \\
\hline Source: Researcher data 2014 & \multicolumn{2}{|l}{}
\end{tabular}

From Table 2 above, majority (51\%) of the respondents indicated that conflicts over papyrus, reeds and other natural resources occurred on a monthly basis whereas $49 \%$ of the respondents indicated that conflicts occurred weekly over these resources.

\subsubsection{Frequency of Conflict over Fish Resources}

Fishing was one of the major economic activities among the residents of lower River Nyando floodplain. The infestation of the lake by the water hyacinth, the recession of the lake water which reduced fishing grounds, the diminishing fish stocks and the government regulation especially fishing ban in certain periods made fishing a difficult economic undertaking and a highly contested resource. Table 3 shows the frequency of conflicts over fish resources.

Table-3. Frequency of Conflicts over Fish Resources

\begin{tabular}{l|l|l}
\hline \multicolumn{1}{c|}{ Duration } & Frequency & Percent \\
\hline Weekly & 14 & 10 \\
\hline Monthly & 25 & 18 \\
\hline Quarterly & 59 & 43 \\
\hline Semi-Annually & 26 & 19 \\
\hline Annually & 14 & 10 \\
\hline Total & $\mathrm{N}=138$ & 100
\end{tabular}


As shown in Table 3 above, 59 respondents (43\%) indicated that conflict over fishing occur in quarterly frequency, followed by 26 respondents (19\%) indicating semi-annually frequency, 25 respondents (18\%) monthly frequency, and 14 respondents (10\%) indicating weekly and annually frequency respectively.

\subsubsection{Frequency of Conflict over Land Resources}

It was important to note that farmers, livestock keepers and even papyrus and reeds harvesters depended on land for their livelihood. The importance and centrality of land among the residents of the flood plain could not be overemphasized. Figure 2 shows the frequency of conflicts over land.

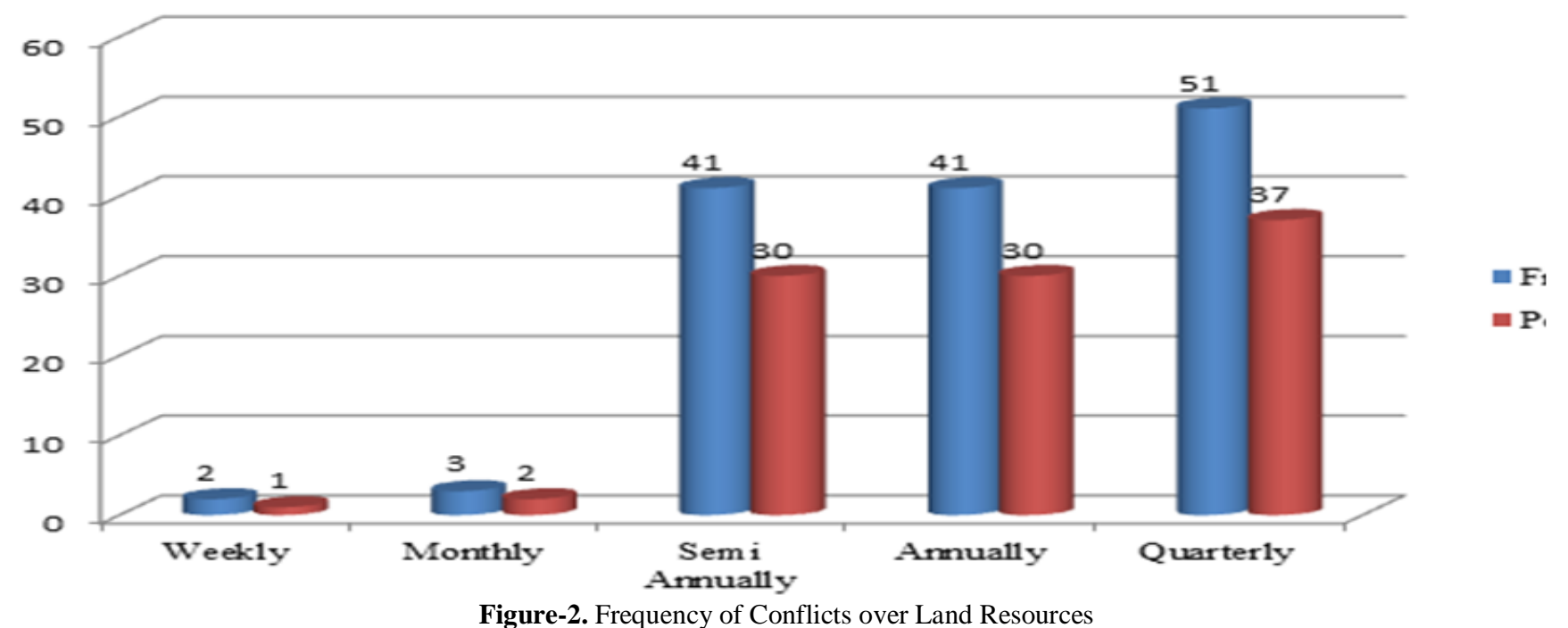

Source: Study data 2014

Figure-2. Frequency of Conflicts over Land Resources

From Figure 2 above, it was evident that $37 \%$ of the respondents indicated quarterly frequency of conflicts over land resources, 30 respondents annually and semi-annually respectively, $2 \%$ monthly whereas $1 \%$ weekly.

\subsection{Result of Conflicts}

After analyzing the frequency of conflicts over landed resources in Lower River Nyando floodplains, it is prudent to establish what such conflicts result into.

\subsubsection{Result of Conflicts over Water}

The researcher first sought to establish what conflicts over water result into in the study area. The respondents indicated that that conflict over water result into several situations like diversion of water by opposing groups, blockage of water tunnels/sources, exclusion of one group(s) from use by the other group(s), and misuse of water so as to create shortage for the other group(s). The frequencies in which various situations occur out of conflict over water are illustrated by Table 4 .

\begin{tabular}{l|l|l|l}
\multicolumn{5}{c}{ Table-4. Effects of conflict over Water } \\
\hline Result of Conflict Over Water & Frequency & Percent & \\
\hline Diversion of Water & 29 & 21.02 & \\
\hline Blockage of Water & 57 & 41.3 & \\
\hline Exclusion from water harvesting & 35 & 25.36 & \\
\hline Misuse of Water & 17 & 12.32 & \\
\hline Total & 138 & 100 & \\
\hline Source: Study data 2014 &
\end{tabular}

According to Table 4 above, blockage of water sources/tunnels were the most (41.3\%) common outcome of conflict over water. Exclusion from use of water sources/tunnels $(25.36 \%)$ followed after blockage of water sources, thereafter diversion of water to areas cultivated by group(s) involved in the diversion $(21.20 \%)$ and lastly, $(12.32 \%)$ of the respondents indicated that misuse of water from the sources so as to create shortages to other group(s) were the outcome of conflict of water in the area.

\subsubsection{Result of Conflicts over Fishing Resources}

The study also sought to establish different outcomes of conflicts over fishing resources in the study area, and the researcher was able to obtained responses as shown in Table 5.

\begin{tabular}{l|l|l} 
Table-5. Result of conflict over Fishing & \multicolumn{2}{l}{} \\
\hline Result of Conflict Over Fishing & Frequency & Percent \\
\hline Destruction of gears & 13 & 9.42 \\
\hline Theft of gears & 92 & 66.67 \\
\hline Exclusion from fishing rights & 30 & 21.74 \\
\hline Others & 3 & 2.17 \\
\hline Total & 138 & 100 \\
\hline Soln
\end{tabular}

Source: Study data 2014 
According to Table 5 above, theft of fishing gears is the most (66.67\%) common outcomes of conflicts over fishing resources. Other outcomes of conflicts over fishing resources were exclusion of fishing rights $(21.74 \%)$ by one group(s), destruction of fishing gears $(9.42 \%)$, and others $(2.17 \%)$ like theft of fish trapped in fishing gears, etc. Thefts of trapped fish was the outcome indicated least by the respondents, and this is due to fears of poisoning on fish catches by the feuding groups.

\subsubsection{Result of Conflicts over Papyrus and Related Resources}

The researcher also sought to find out the outcome of conflicts over exploitation of papyrus in the study area, and the respondents were asked to indicate whether or not the stated situations resulted from such conflict. Table 6 illustrates the responses obtained by the researcher.

\begin{tabular}{l|l|l} 
Table-6. Effects of Conflict over Papyrus and related resources \\
\hline Result of Conflict Over Papyrus Resources & Frequency & Percent \\
\hline Destruction of wet papyrus & 20 & 14.49 \\
\hline Burning of dried papyrus & 55 & 39.86 \\
\hline Theft of Dried papyrus & 48 & 34.78 \\
\hline Exclusion from papyrus harvesting & 15 & 10.87 \\
\hline TOTAL & 138 & 100 \\
\hline Source: Study data 2014 &
\end{tabular}

Destruction of dried papyrus (39.86\%) by opposing group(s) and theft (or confiscation) of dried papyrus $(34.78 \%$ ) was found to be the most common outcomes of conflicts over papyrus and related resources as is illustrated by Table 6 . Other results arising out of such conflicts as indicated by the respondents include destruction of wet papyrus $(14.49 \%)$, and exclusion from the right to exploit papyrus products $(10.87 \%)$.

\subsubsection{Result of Conflicts over Land}

The result of conflict over land is as shown in Table 7.

\begin{tabular}{l|l|l} 
Table-7. Result of Conflict over Land & Frequency & Percent \\
\hline Result of Conflict Over Land & 13 & 9.42 \\
\hline Exclusion from Farming Right & 9 & 6.52 \\
\hline Restriction of livestock passage & 30 & 21.74 \\
\hline Denial of grazing rights & 86 & 62.32 \\
\hline Destruction of Crops & 138 & 100 \\
\hline TOTAL &
\end{tabular}

Table 7 above indicates that most (62\%) of the respondents view destruction of crops as the most common outcome of conflict over land. Similarly, $22 \%$ of the respondents stated that these conflicts over land often result into exclusion of grazing rights by the rival clans, while $9 \%$ and $7 \%$ of the respondents indicated that exclusion from farming and livestock passage rights respectively, are the results emanating from conflict over land between the warring clans.

\subsection{Effects of Conflicts on Gender}

The last objective of the study sought to determine the effect of conflict on different categories of gender, namely men, women, youth, elderly men, and disabled. As shown in Table $844 \%$ of the respondents stated that women are the most affected members among the conflicting groups, followed by the youth (26\%), men (17\%), disabled persons $(9 \%)$ and finally elders (4\%). This is shown in Table 8.

\begin{tabular}{l|l|l} 
Table-8. Effects of conflicts on gender & Percent \\
\hline Gender & Frequency & 44 \\
\hline Women & 60 & 17 \\
\hline Men & 24 & 4 \\
\hline Elders & 6 & 26 \\
\hline Youth & 36 & 9 \\
\hline Disabled & 12 & 100 \\
\hline Total & 138 & \\
Source: Study data 2014 &
\end{tabular}

\subsubsection{Effects of Conflicts on Women}

Women were found by the study to suffer as a result of common pool resource conflict in this area, as Figure 3 illustrates. 


\section{Effect of Conflict on Women}

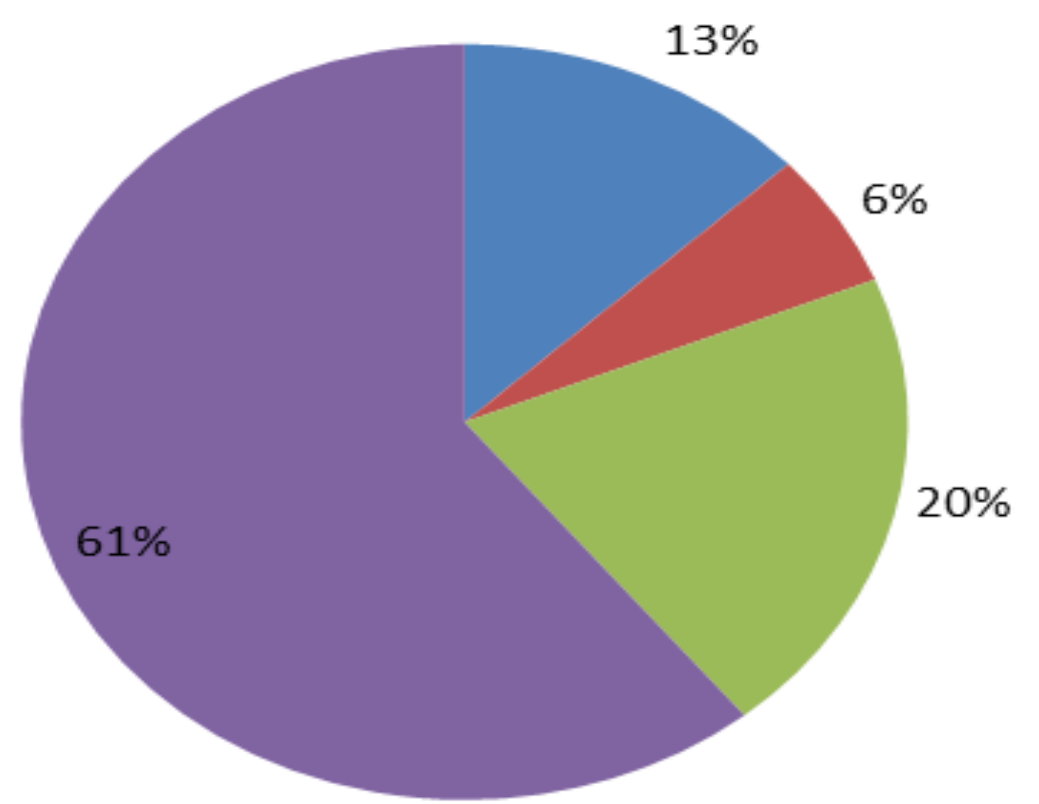

Fatal loss of husbands

Body injuries

Household stress

Crop losses

Source: Study data 2014

Figure-3. Effect of conflict on Women

As Figure 3 illustrates, $61 \%$ of the respondents indicated that women suffer from loss of crops due to common pool resource conflict in this area when their crops are damaged or they are excluded from cultivation rights; related to this, household stress (20\%) was indicated by the respondents to the other effect over common resource in Lower River Nyando floodplains. The study also found that women in this area also suffer from loss of husbands through fatal injuries obtained from the battle field (13\%). Similarly, women were also found to suffer from body injuries $(6 \%)$ inflicted on them by their feuding partners in the conflict zones, either through battery or rape.

\subsubsection{Effects of Conflict on Men}

Common pool resource conflict in the study area has had grave effect on men. Figure 9 illustrates this.

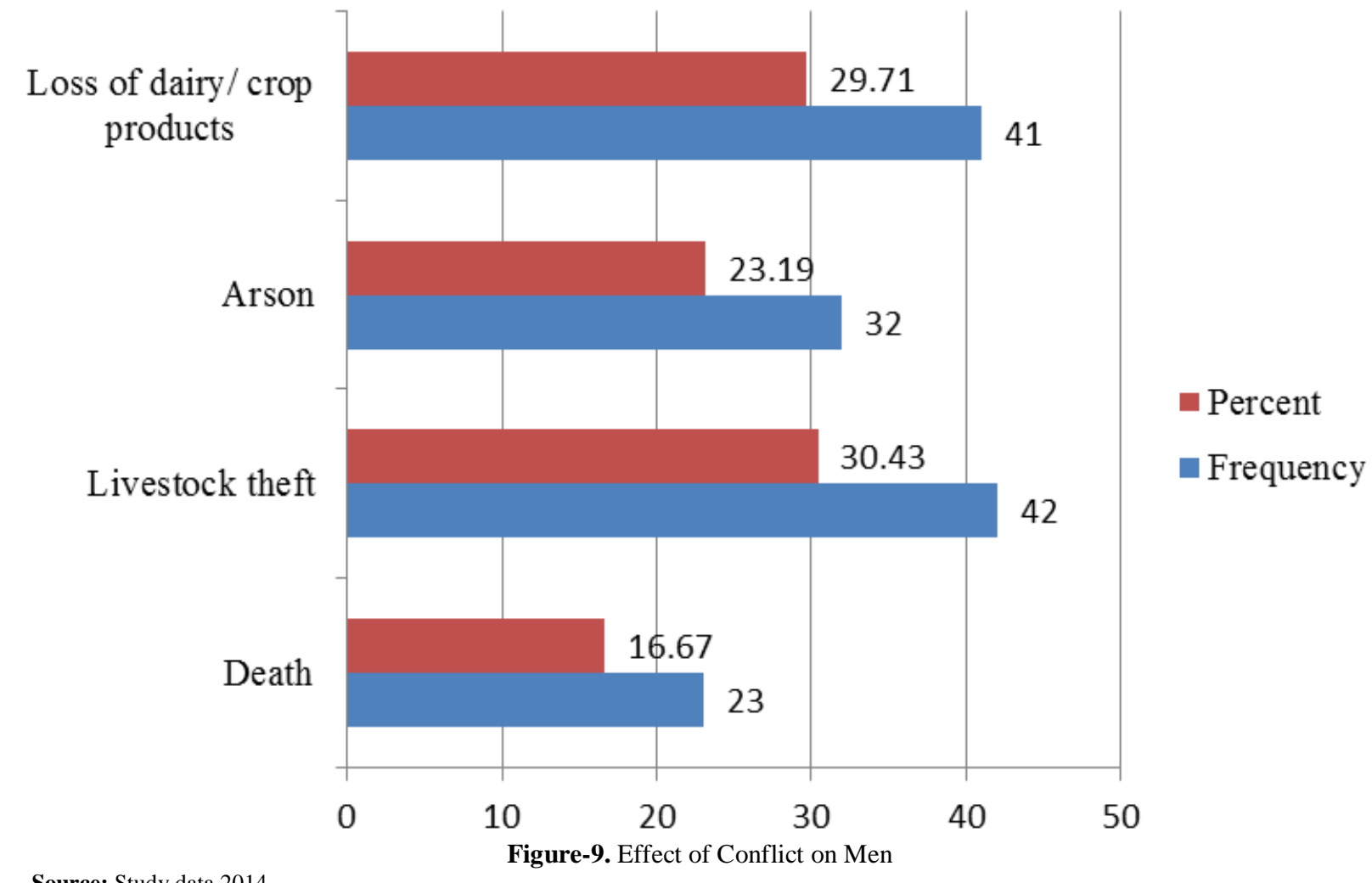

Loss of livestock $(30.43 \%)$ was indicated by most respondents as the gravest effect of conflict on men; and related to this, men also suffered from loss of livestock/crop related products (27.71\%). Men in this area were also found to suffer from loss of shelter (23.19\%) through arson by the conflicting counterparts. In some extreme cases, men involved in the conflict loss lives $(16.67 \%)$ in the battle field.

\subsubsection{Effects of Conflict on Elderly Persons}

The study found that elderly persons are also victims of these conflicts in various manners as Figure 6 illustrates. 


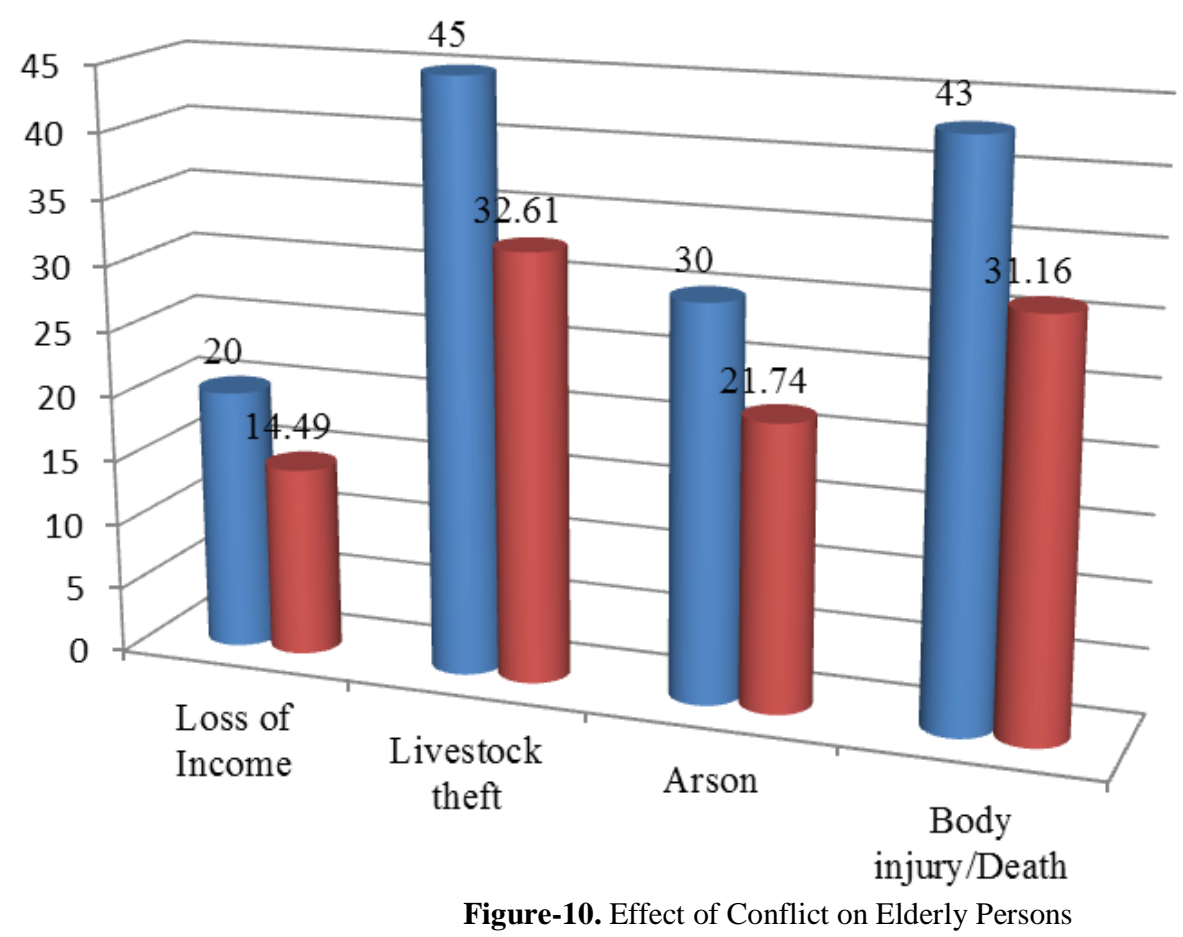

Frequency

- Percent

Source: Study data 2014

Figure-10. Effect of Conflict on Elderly Persons

The respondents in this study indicated that elderly persons suffer most (32.61\%) from livestock theft; another $31.16 \%$ of the respondents stated that elderly persons are affected when their sons obtain body injuries or get killed $(31.16 \%)$ in the battle field during these conflicts. Loss of shelter through arson $(21.74 \%)$ and loss of income $(14.49 \%)$ are the other effects of conflict that elders face, according to the respondents.

\subsubsection{Effect of Conflict on Youth}

The youths were also found to be affected by these conflicts over common pool resource in this area, as Table 9 illustrates.

Table-9. Effect of Conflict on Youth

\begin{tabular}{l|l|l|l|l}
\hline Respondents & Exclusion from schools & Loss of Lives & Restriction from social joints & Total \\
\hline Frequencies & 61 & 34 & 43 & 138 \\
\hline Percent & 44.2 & 24.64 & 31.16 & 100 \\
\hline
\end{tabular}

According to Table 9 above, most (44.2\%) of the respondents stated that the youths are excluded from schools which are situated in the regions occupied by the rival clans, and another $31.16 \%$ of the respondents indicated that the youths are denied access to social joints situated in regions occupied by rival clans. The respondents also indicated that the youths often loss lives $(24.64 \%)$ during clashes occasioned by conflict over common resources in this area.

\subsubsection{Effect of Conflict on the Disabled}

The last category of gender which the study found to be affected by conflict in this area was the disabled members from the conflicting clans. Table 10 illustrates the responses that the researcher obtained from the respondents.

Table-10. Effect of Conflict on the Disabled

\begin{tabular}{l|l|l|l|l}
\hline Respondents & Denial of access to basic assistance & Loss of Lives & Restriction of Passage rights & Total \\
\hline Frequencies & 49 & 34 & 55 & 138 \\
\hline Percent & 35.51 & 24.64 & 39.85 & 100 \\
\hline
\end{tabular}

As Table 10 indicates, most $(39.85 \%)$ stated that the disabled members from the warring clans are often restricted from passing in regions where rival clans occupy. Another $35.51 \%$ of the respondents indicated that the disabled persons from the feuding clans are normally denied access to basic support offered in regions that are occupied by the rival clans. Lastly, $24.64 \%$ of the respondents stated that in extreme occasions, the disabled loss their lives when they are attacked by groups from the rival clans.

\section{Discussions and Conclusions}

\subsection{Discussions}

The study established that conflict over common pool resources occur in this area most on monthly and quarterly basis, and these result into diverse consequences depending on the resource over which the conflict is occurring. As enthused by Chitiyo [6] any type of conflict is deleterious for the livelihoods of the resource-dependent communities as well as society as a whole. Exclusion from the right to utilize common pool resource is found to be the most prevalent outcome of conflict in this area.

This finding is in line with Cooke, et al. [20] explanation that dry and remote areas often experience feuds due to scarcity of grazing, water, and other common resources over which the entire community rely for their livelihood. 
Similarly, conflicts over common resources in this area have had a lot of grave effect on women in particular; from exclusion, diversion or blockage of water sources to the destruction of crops, alongside loss of husbands through death in the battlefields. This corresponds with Meur, et al. [21] and Sanginga, et al. [2] observation that local disputes may often intensify to bloodshed and death, and such rivalries can linger under surface for several decades.

This study also found that men often lose sources of livelihood when they (men) are excluded from the right of grazing and cropping during conflict escalation, and to extreme circumstances, their lives.

This is in agreement with the findings of Deininger and Castagnini [3] in their study on conflicts in northern Uganda, that survival during conflict is often at stake in such conflicts with potentially wasteful use of human capital and depletion of the resources necessary for individual and community livelihoods putting the long-term peaceful coexistence of various groups in jeopardy, and bloodshed may be an extreme, but a possible outcome. Similarly, it can be seen that the school going youths remain at home due restrictions on access to schools situated in regions occupied by rivals, and are also denied the right to enjoy in social joints situated in areas occupied by rivals. Ohlsson [5] also found a similar situation in Rwanda during the genocide of 1990s, where youths abandoned school altogether and joined the clashes [8].

Elderly persons and the disabled have also been found to be affected by conflict over common resource. These are categories of gender that rely on peaceful co existence for smooth life. The crops and dairy products which support economically this class of residents get destroyed or are subjected to hunger due to exclusion from the right to cultivate or crop by the rival groups.

Conflict caused by unclear tenure rights, competition between traditional and modern rights systems, inheritance disputes, and weak institutional environment to support land reforms in Uganda was found to lower land productivity by inflicting crop damage, including perennial crops, leaving land unused as a result of fear to cultivate, and undermining land markets by Deininger and Castagnini [3]. These outcomes lead to diminished productivity of land, forcing more disadvantaged segments such as widows to make sub-optimal use of their land by depriving them of potential rental income, and resulting in an overall sub-optimal social land use.

\subsection{Conclusions}

With effect of conflict on gender, the frequency of conflict occurrence is often between monthly and quarterly basis in Lower River Nyando floodplains. These conflicts often result into exclusion from the right of use the disputed common pool resource, destruction of the products in the disputed common resource, and wasteful usage of the disputed resource. In turn, this affects the various categories of gender by causing household poverty due to loss of livelihood, and to extreme extent, causes death or body injuries. In many occasions, youths are denied the right to attend school and free interaction.

\section{References}

[1] D. C. Edossa, S. B. Awulachew, R. E. Namara, M. S. Babel, and A. Das Gupta, Indigenous systems of conflict resolution in Oromia, Ethiopia. In community-based water law and water resource management in developing countries, B. Van Koppen, M Giordano, and J. Butterworth, Ed. United Kingdom: CAB International, 2007.

[2] P. Sanginga, R. Kamugisha, and A. Martin, "The dynamics of social capital and conflict management in multiple resource regimes: A case of the southwestern highlands of Uganda," Ecology and Society, vol. 12, p. 6, 2007.

[3] K. Deininger and R. Castagnini, Incidence and impact of land conflicts in Uganda. Washington, DC: World Bank Policy Research Working Paper No. 3248. The World Bank, 2004.

[4] D. Buckles and G. Rusnak, Introduction: Conflict and collaboration in natural resource management, in cultivating peace: Conflict and collaboration in natural resource management. D. Buckles, Ed. Ottawa, Canada: International Development Research Centre, 1999.

[5] L. Ohlsson, Livelihood conflicts; Linking poverty and environment as causes of conflict. Stockholm, Sweden: Environmental Policy Unit, Sida, 2000.

[6] T. Chitiyo, Violence and compensation: Reconceptualizing Zimbabwe's land and war veteran debate. In Demilitarilization and peace building in Southern Africa. National and regional experiences, Batcher P. and K. Kingma. Eds vol. 2. Burlington, VT: Ashgate Publishing Company, 2004.

[7] Economist, "Intelligence unit, 3rd quarter," 1999.

[8] International Crisis Group (ICG), "Georgia - avoiding war in South Ossetia," Europe Report No 159, Tbilisi/Brussels. Available http://www.crisisgroup.org/. [Accessed 2008-05-12], 2004.

[9] B. Thebaud and S. Batterbury, "Sahel pastoralists: Opportunism, struggle, conflict and negotiation; a case study from Eastern Nige," Global Environmental Change, vol. 11, pp. 69-78, 2001.

[10] E. Nkonya and H. Markelova, Looking beyond the obvious: Uncovering the features of natural resource conflicts in Uganda. CAPRi Working Paper No. 95. Washington, DC: International Food Policy Research Institute. Available http://dx.doi.org/10.2499/CAPRiWP95, 2009.

[11] D. Carney, Sustainable rural livelihoods; what contribution can we make. London: DFID/ODI, 1998.

[12] P. Hoon, N. Singh, and S. Wanmali, Sustainable livelihoods: Concepts, principles and approaches to indicator development. A draft discussion paper. New York: UNDP, 1997.

[13] W. Sunderlin, A. Angelsen, B. Belcher, P. Burgers, R. Nasi, L. Santoso, and S. Wunder, "Livelihoods, forests, and conservation in developing countries: An overview," World Development, vol. 33, pp. 1383-1402, 2005.

[14] WRI (World Resources Institute), "The wealth of the poor: Managing ecosystems to fight poverty," World Resources Report; Washington, DC: United Nations Development Programme, United Nations Environment Programme, World Bank, and World Resources Institute, 2005.

[15] T. Dietz, E. Ostrom, and P. C. Stern, "The struggle to govern the commons," Science, vol. 302, pp. 1907-1912, 2003.

[16] M. Kugelman and S. Levenstein, Land grab? The race for the world's Farmland. Washington, DC: Woodrow Wilson International Center for Scholars, 2009.

[17] I. Bannon and P. Collier, Natural resources and violent conflict. Washington, DC: World Bank, 2003.

[18] MAAI Report, "Ministry of agriculture and animal industry of Uganda," Annual Report, 2007.

[19] GoK, Nyando district development plan. Nairobi: Government Printer, 2008.

[20] P. Cooke, G. Köhlin, and W. Hyde, "Fuelwood, forests and community management - evidence from household studies," Environment and Development Economics, vol. 13, pp. 103-135, 2008. 
[21] P. Y. Meur, P. Hochet, M. Shem, and O. Touré, "Conflict over access to land \& water resources within Sub-Saharan dry lands; underlying factors, conflict dynamics and settlement processes," GRET-FAO LEAD Final Report; Groupe De Recherche et D’Echanges Technologiques 211-213 Rue La Fayette 75010 Paris, France, 2006.

\section{Bibliography}

[1] B. Upretti, "Land conflict in Nepal: Peasants'struggle to change unequal agrarian social relations," Community, Work and Family, vol. 7, pp. 371-393, 2004b 